\title{
Compromised Respiratory Function in Postnatal Lambs after Placental Insufficiency and Intrauterine Growth Restriction
}

\author{
BELINDA J. JOYCE, SAMANTHA LOUEY, MARCUS G. DAVEY, MEGAN L. COCK, \\ STUART B. HOOPER, AND RICHARD HARDING \\ Fetal and Neonatal Research Group, Department of Physiology, Monash University, \\ Victoria 3800, Australia
}

ABSTRACT

\begin{abstract}
Epidemiologic studies have shown persistent effects of low birth weight on respiratory function and lung health, but underlying mechanisms are not understood. Our aim was to determine the effects of intrauterine growth restriction (IUGR), a major cause of low birth weight, on postnatal respiratory function. IUGR was induced by umbilico-placental embolization during late gestation in chronically catheterized sheep. Umbilicoplacental embolization was performed between $120 \mathrm{~d}$ of gestation and term ( $\sim 146 \mathrm{~d})$ during which fetuses were hypoxemic and hypoglycemic relative to controls. Umbilico-placental embolization led to a $48 \%$ reduction in birth weight compared with controls, and throughout the postnatal study period IUGR lambs $(n=8)$ remained lighter than controls $(n=8)$. Respiratory function was repeatedly studied in lambs for 8 wk after birth; during this period, IUGR lambs were mildly hypoxemic and tended to be hypercapnic compared with controls. In IUGR lambs, relative to controls, $\mathrm{O}_{2}$ consumption $(\mathrm{mL} / \mathrm{min} / \mathrm{kg})$ and minute ventilation $(\mathrm{mL} / \mathrm{kg})$ were increased and pulmonary diffusing capacity (adjusted for functional residual capacity) was decreased. Functional residual capacity, measured by helium dilution, and total lung capacity (measured at $30 \mathrm{~cm} \mathrm{H}_{2} \mathrm{O}$ ) were smaller in IUGR lambs than in controls. When adjusted for functional residual capacity, static lung compliance was reduced and chest wall compliance was increased in IUGR lambs. At 8
\end{abstract}

wk, pulmonary DNA and protein concentrations were decreased in IUGR lambs relative to controls. We conclude that restriction of fetal growth by placental insufficiency induces alterations in the lungs and chest wall that result in persistent impairments in respiratory function during early postnatal life. (Pediatr Res 50: 641-649, 2001)

BWt, body weight

\section{Abbreviations}

$\mathbf{C}_{\mathbf{L}}$, lung compliance

$\mathbf{C}_{\mathbf{R S}}$, compliance of the respiratory system

$\mathbf{C}_{\mathbf{W}}$, chest wall compliance

CRL, crown-rump length

DLco, diffusing capacity of the lung for carbon monoxide

FRC, functional residual capacity

IUGR, intrauterine growth restriction

$\mathrm{PaCO}_{2}$, arterial $\mathrm{PCO}_{2}$

pHa, arterial $\mathrm{pH}$

$\mathrm{PaO}_{2}$, arterial $\mathrm{PO}_{2}$

$\mathrm{SaO}_{2}$, percent saturation of arterial blood with oxygen

SP, surfactant protein

TLC $_{\mathbf{3 0}}$, total lung capacity at $30 \mathrm{~cm} \mathrm{H}_{2} \mathrm{O}$

UPE, umbilico-placental embolization
Restricted fetal growth, resulting in low birth weight, has been associated with altered lung development and impaired respiratory function after birth. Recent studies of neonates and infants who have been growth restricted in utero indicate that they have an increased risk of mortality and morbidity (1), including respiratory distress $(2,3)$. Respiratory compromise may persist during postnatal development as it has been shown that children with evidence of growth restriction in utero have

Received May 11, 2000; accepted March 13, 2001.

Correspondence and reprint requests: Belinda J. Joyce, Department of Physiology, P.O. Box 13F, Monash University, Victoria 3800, Australia; e-mail: belinda.joyce@med.monash.edu.au

This study was supported by the NH\&MRC of Australia. reduced forced expiratory flow rates $(4,5)$ indicative of impaired airway function. In addition, adults who were of low birth weight and, therefore, likely to have been growth restricted in utero, have reduced expiratory flow rates and an increased risk of respiratory morbidity and mortality $(6,7)$. Thus, a number of epidemiologic studies suggest that pulmonary gas exchange and airway function after birth may be affected by IUGR.

Placental insufficiency and IUGR are common causes of low birth weight, and are associated with pregnancy-induced hypertension, maternal tobacco smoking, and placental pathology $(8,9)$. Fetuses identified as being growth restricted have been found to be hypoxemic, hypoglycemic, and to have elevated 
plasma cortisol concentrations (10-12). Individually, each of these factors has been shown to affect prenatal lung development; elevated circulating cortisol concentrations have been shown to advance lung maturation (13), whereas hypoxemia (14) and undernutrition (15) have been shown to retard lung maturation. However, to date, there appear to have been no experimental studies on the consequences of IUGR induced by placental insufficiency on postnatal lung function. Thus, our objective was to characterize alterations in postnatal lung function, and their persistence, resulting from the restriction of fetal growth. Our hypothesis was that placental insufficiency and restricted fetal growth, coincident with the later stages of fetal lung development, would cause persistent impairments of lung function after birth.

We have chosen to induce IUGR in sheep during late gestation by UPE as this technique replicates many of the features of growth-restricted human fetuses, including hypoxemia, hypoglycemia (11), and hypercortisolemia (12). Furthermore, many of the metabolic, cardiovascular, and endocrine effects of UPE in ovine pregnancy have been documented (16-18). The period of IUGR that we used, $120 \mathrm{~d}$ of gestation to term, coincides with the alveolar stage of lung development in sheep (19). To gain a greater understanding of the persistence of effects on respiratory function we have made repeated studies of the same postnatal animals until 8 wk after birth, when lung tissue was collected for analysis of factors likely to affect lung function. We also measured surfactant proteins as they have not previously been measured in postnatal animals after IUGR.

\section{MATERIALS AND METHODS}

Surgical procedures. Aseptic surgery was performed on 12 pregnant crossbred ewes at $115 \pm 1 \mathrm{~d}$ (mean $\pm \mathrm{SD}$ ) after mating (term $\sim 146 \mathrm{~d}$ ). Under general anesthesia (1.5-2\% halothane in $\mathrm{O}_{2}$ ), the maternal abdominal wall and uterus were incised to expose the fetal hindquarters. Polyvinyl catheters were inserted into a fetal femoral artery and vein. The arterial catheter was inserted approximately $6-7 \mathrm{~cm}$ such that its tip lay in the abdominal aorta below the renal arteries; this catheter was used for blood sampling and injection of microspheres for placental embolization (18). The venous catheter was used for administration of drugs before and after birth. Catheters were tunneled beneath the fetal skin, emerging over the rump to which they were sutured. A polyvinyl catheter was inserted into the amniotic sac so that amniotic fluid pressure could be measured for the detection of labor. We administered procaine penicillin and dihydrostreptomycin (Depomycin; Intervet, Sydney, NSW, Australia) to the fetus before the uterus was sutured closed. Stainless steel electrodes were sutured to the myometrium to monitor the uterine electromyogram (EMG) during labor. After surgery, sheep were housed in individual cages with 12-h light (07.00-19.00) and dark cycles.

Experimental protocol. Animals were allowed 3-5 d of postsurgical recovery before embolization began. Embolization was induced in eight fetuses (six twins, two singletons) from $120 \mathrm{~d}$ of gestation until the onset of labor. Control fetuses (all singletons) received either saline injections $(n=6)$ or no fetal surgery $(n=2)$. To induce UPE, insoluble mucopolysaccharide microspheres (Sephadex G25, Pharmacia, Uppsala, Sweden, $40-75 \mu \mathrm{m}$ ) were suspended at $1 \% \mathrm{wt} / \mathrm{vol}$ in heparinized saline with $0.02 \%$ Tween 80 , such that $1 \mathrm{~mL}$ of solution contained approximately $10^{6}$ microspheres. Daily injections of microspheres were made until the fetal arterial $\mathrm{Hb}$ saturation $\left(\mathrm{SaO}_{2}\right)$ fell to $25-35 \%$ (18). Fetal arterial blood samples were taken daily for the measurement of gas tensions and $\mathrm{pH}$, and glucose and lactate concentrations. Fetal plasma was collected every 3-4 d, at least $2 \mathrm{~h}$ after UPE, for analysis of cortisol concentrations. Daily UPE and blood sampling continued until the onset of labor. These studies were performed after institutional ethical approval had been obtained.

Birth of lambs. All lambs used in this study were born spontaneously per vaginum at term; lambs born preterm $(<140$ d) were excluded. Uterine activity was monitored from $140 \mathrm{~d}$ of gestation by continuously recording myometrial EMG activity and/or amniotic fluid pressure. When labor was detected, fetal catheters were shortened and obstructed and retaining sutures removed, allowing free passage of catheters with the lamb during birth. When in labor, ewes were closely monitored until lambs were born, delivery being assisted if necessary. Immediately after birth, lambs were weighed, an arterial blood sample taken, and rectal temperature measured. Lambs were closely monitored for at least the first $24 \mathrm{~h}$ to ensure that they had consumed colostrum and were feeding regularly, and that their rectal temperatures were within the normal range. All lambs were raised by their mothers but, if necessary, they were provided with formula milk suitable for lambs.

Measurement of respiratory function. Lambs were removed from their mothers, weighed, and studied while lying prone in a sling at $3.2 \pm 1.1 \mathrm{~d}(0.5 \mathrm{wk}), 7.5 \pm 0.9 \mathrm{~d}(1 \mathrm{wk})$, $15.4 \pm 1.8 \mathrm{~d}(2 \mathrm{wk}), 27.9 \pm 1.8 \mathrm{~d}(4 \mathrm{wk})$, and $53.8 \pm 2.4 \mathrm{~d}(8$ wk) after birth. The techniques we used have been described in detail previously (20), and only a brief outline is given here. Before each lung function study, arterial blood samples were taken for analysis of gas tensions, $\mathrm{pH}$, glucose and lactate concentrations, and cortisol concentrations; lambs were weighed and CRL measured. Lambs were then sedated with either Saffan (a mixture of alphaxalone, $90 \mathrm{mg} / \mathrm{h}$, and alphadolone, $30 \mathrm{mg} / \mathrm{h}$, Pitman Moore, Sydney, NSW, Australia, i.v.) or pentobarbital (Nembutal, Rhone Merieux, Brisbane, Qld, Australia, $5-15 \mathrm{mg} / \mathrm{kg} / \mathrm{h}$ i.v.) so that they could be intubated for performance of lung function tests (20); sedation was an ethical requirement for intubation. Lambs were sedated with Saffan when they weighed less than $8-9 \mathrm{~kg}$, after which they received pentobarbital.

Ventilation and oxygen consumption. Tidal volume, minute ventilation, and breathing frequency were recorded digitally (MacLab, ADI, Sydney, NSW, Australia) using a pneumotachograph attached to the endotracheal tube. Oxygen consumption was measured while lambs breathed from a sealed spirometer containing $\mathrm{O}_{2}$. Measurements were made for approximately 30 min from each animal.

Gas volumes and diffusing capacity. FRC and DLco were measured, respectively, by helium dilution and by a carbon monoxide rebreathing method (21); FRC was measured once per study day, and DLco was measured three times, and the 
mean taken. $\mathrm{TLC}_{30}$ was calculated as the sum of $\mathrm{FRC}$ and expiratory volume following inflation of the lungs to $30 \mathrm{~cm}$ $\mathrm{H}_{2} \mathrm{O}$. The expired volume was measured while lambs were apneic following a short period of hyperventilation; the lungs were inflated to $30 \mathrm{~cm} \mathrm{H}_{2} \mathrm{O}$ and then allowed to deflate passively to FRC into a spirometer $(20,22)$.

Lung and chest wall compliances. Static compliances of the respiratory system were obtained during apnea from measurements of increments in lung volume when the lungs were exposed to an airway pressure of $30 \mathrm{~cm} \mathrm{H}_{2} \mathrm{O}$. Intrapleural pressure was measured using a latex intraesophageal balloon, allowing $C_{R S}$ to be partitioned into $C_{L}$ and $C_{W}(20,22)$. We expressed compliances in relation to $\mathrm{FRC}$.

Postmortem tissue analysis at $8 \boldsymbol{w} \boldsymbol{k}$. At the end of the 8-wk postnatal study period, lambs were painlessly killed with an overdose of pentobarbital sodium (i.v.). Major organs were weighed and, after ligating the left bronchus, portions of the left lung were snap frozen in liquid $\mathrm{N}_{2}$ and stored at $-70^{\circ} \mathrm{C}$ for molecular and biochemical analysis. The right lung was infused with paraformaldehyde at $20 \mathrm{~cm} \mathrm{H}_{2} \mathrm{O}$ for histologic analysis (23).

Surfactant protein analyses. SP-A, -B, and -C mRNA levels were quantified by Northern blot analysis, on separate blots and were repeated at least twice (24). We used ovine specific SP-A, -B and -C cDNA probes labeled with ${ }^{32} \mathrm{P}-\mathrm{dCTP}$ using a random-priming labeling kit and quantified by exposure to a storage phosphor screen for $24-48 \mathrm{~h}$ (24). The amount of RNA loading between lanes was standardized by stripping and rehybridizing the membranes with a ${ }^{32} \mathrm{P}$-labeled probe for $18 \mathrm{~S}$ rRNA. The relative amounts of each surfactant protein and $18 \mathrm{~S}$ rRNA were quantified by densitometry and SP-A, -B, and -C mRNA levels were expressed as ratios with $18 \mathrm{~S}$ rRNA levels.

SP-A protein levels in lung tissue were measured by Western blot analysis (24). Proteins extracted from lung tissue (200-300 mg) were denatured and separated by SDS-PAGE and then transferred to a nitrocellulose membrane by electrotransfer. The membrane was washed and incubated with ovine SP-A antibody (donated by Dr. S. Hawgood, University of California San Francisco), before it was again washed and then incubated with the secondary antibody (goat anti-rabbit IgG). The washed membrane was exposed to chemiluminescence reagents and exposed to film. The autoradiograph was scanned to measure densities of the SP-A protein bands.

DNA, protein, and cortisol assays. Pulmonary DNA and soluble protein concentrations were determined using, respectively, an established fluorometric DNA assay (25) and a standard colorimetric protein assay (Bio-Rad, Hercules, CA, U.S.A.). Protein standards were prepared using BSA (A-7888, Sigma Chemical, St. Louis, MO, U.S.A.) made up as a 100 $\mu \mathrm{g} / \mathrm{mL}$ solution with distilled water and diluted to give concentrations of $6.25-100 \mu \mathrm{g} / \mathrm{mL}$. Plasma cortisol concentrations were determined using an established RIA (26).

Statistical analysis. Data are presented as mean \pm SD. Fetal and postnatal blood data, ventilation, oxygen consumption, gas volumes, DLco, and respiratory compliances were analyzed by two-way repeated measures ANOVA (treatment and age as factors). Significant differences between means were identified with a posthoc least significant difference test at $p<0.05$ (27).
To determine the most appropriate adjustment factor for lung volume data, we performed stepwise multiple linear regression analysis, with independent variables being body weight, CRL, and treatment group (IUGR). Data on body and organ weights, surfactant proteins and pulmonary DNA and protein concentrations were analyzed by unpaired $t$ tests; statistical significance was taken as $p<0.05$.

\section{RESULTS}

Fetal blood data. Throughout the UPE period, IUGR fetuses remained hypoxemic compared with controls (Fig. 1, Table 1). Compared with control fetuses, $\mathrm{PaCO}_{2}$ was higher in IUGR fetuses, and $\mathrm{pH}$ was slightly lower close to term; Hb concentrations were not significantly altered (Table 1). Arterial glucose concentrations in IUGR fetuses were lower than in controls $(0.5 \pm 0.3$ versus $0.8 \pm 0.2 \mathrm{mmol} / \mathrm{L}$, Fig. 1$)$. Blood lactate concentrations did not differ between groups (Table 1). Plasma cortisol concentrations increased in both IUGR and control fetuses during late gestation, reaching similar levels before the onset of labor (Fig. 1).

Postnatal growth. Lambs subjected to UPE were born $2 \mathrm{~d}$ earlier than controls $(145 \pm 2 \mathrm{~d}$ versus $147 \pm 2 \mathrm{~d}, p<0.05)$ and weighed $48 \%$ less than controls $(2.5 \pm 0.7 \mathrm{~kg}$ versus $4.8 \pm$ $1.0 \mathrm{~kg}, p<0.05$ ). IUGR lambs were lighter (Fig. 2) and CRL was shorter than controls throughout the 8 -wk postnatal period.
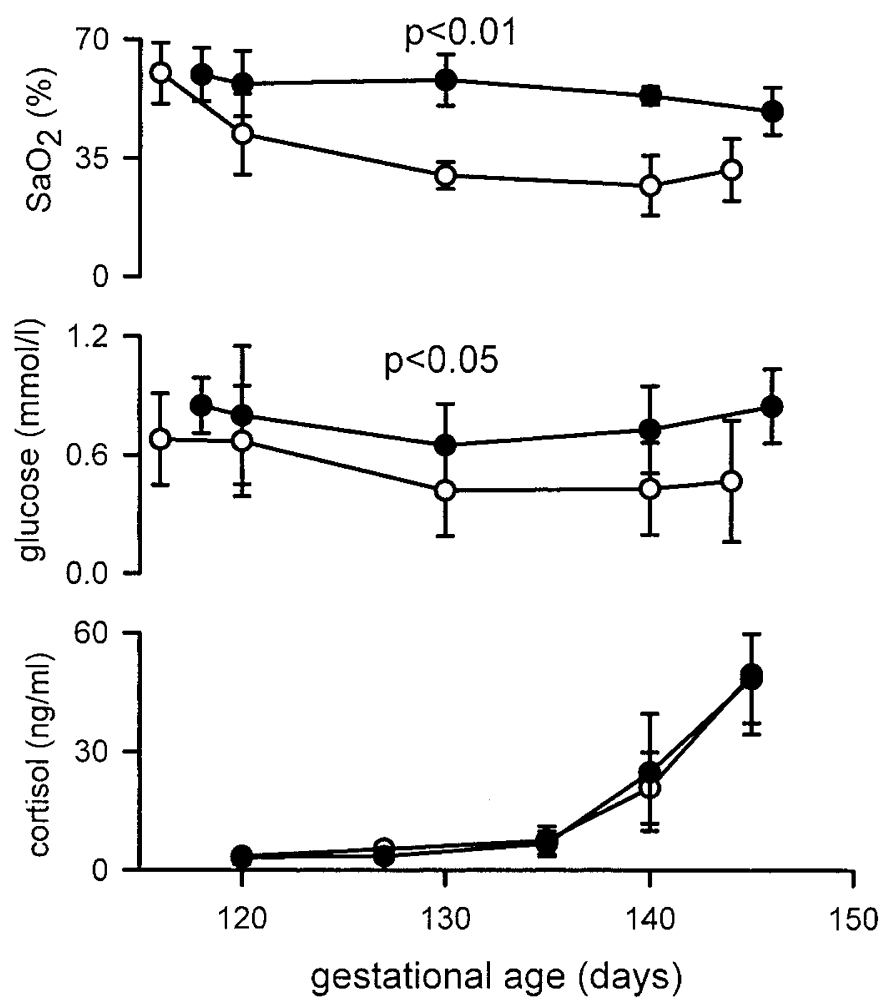

Figure 1. Arterial oxygen saturation and concentrations of glucose and cortisol during the period of UPE in fetuses that were later studied as postnatal lambs. The period of UPE began at $120 \mathrm{~d}$ of gestation. Data (mean $\pm \mathrm{SD}$ ) from IUGR fetuses are shown by $\bigcirc$; show data from control fetuses. IUGR fetuses became hypoxemic and hypoglycemic during the period of UPE $(p<$ 0.05). In both groups of fetuses, plasma cortisol concentrations increased toward term but there was no significant effect of UPE. Where SD bars cannot be seen, they fall within the symbols. 
Table 1. Measurements (mean $\pm S D)$ made in arterial blood from control $(\mathrm{n}=6)$ and IUGR $(\mathrm{n}=8)$ fetuses during umbilico-placental embolization (UPE) from 120 d of gestation until the onset of labor at term

\begin{tabular}{|c|c|c|c|c|c|}
\hline & & $119 \mathrm{~d}$ & $130 \mathrm{~d}$ & $140 \mathrm{~d}$ & $\operatorname{Term}(\sim 146 \mathrm{~d})$ \\
\hline \multirow[t]{2}{*}{$\mathrm{PaO}_{2}(\mathrm{~mm} \mathrm{Hg})$} & Control & $21.1 \pm 2.6$ & $20.4 \pm 1.8$ & $20.1 \pm 1.6$ & $20.9 \pm 2.9$ \\
\hline & IUGR & $18.9 \pm 1.7$ & $13.0 \pm 1.6^{*}$ & $10.7 \pm 3.6^{*}$ & $14.2 \pm 2.8^{*}$ \\
\hline $\mathrm{PaCO}_{2}(\mathrm{~mm} \mathrm{Hg})$ & Control & $45.8 \pm 3.5$ & $50.6 \pm 2.2$ & $45.4 \pm 4.0$ & $46.9 \pm 4.8$ \\
\hline \multirow[t]{2}{*}{$\mathrm{pHa}$} & Control & $7.34 \pm 0.05$ & $7.36 \pm 0.03$ & $7.39 \pm 0.03$ & $7.37 \pm 0.02$ \\
\hline & IUGR & $7.38 \pm 0.02$ & $7.36 \pm 0.01$ & $7.36 \pm 0.02$ & $7.31 \pm 0.03^{*}$ \\
\hline Hemoglobin $(\mathrm{g} / \mathrm{dL})$ & Control & $10.7 \pm 0.9$ & $11.9 \pm 1.0$ & $11.8 \pm 1.0$ & $13.2 \pm 1.4$ \\
\hline Lactate $(\mathrm{mmol} / \mathrm{L})$ & IUGR & $0.7 \pm 0.1$ & $0.9 \pm 0.2$ & $0.8 \pm 0.2$ & $0.7 \pm 0.2$ \\
\hline
\end{tabular}

Data at $119 \mathrm{~d}$ preceded the onset of UPE. Asterisks $(*)$ indicate differences between groups $(p<0.05)$.

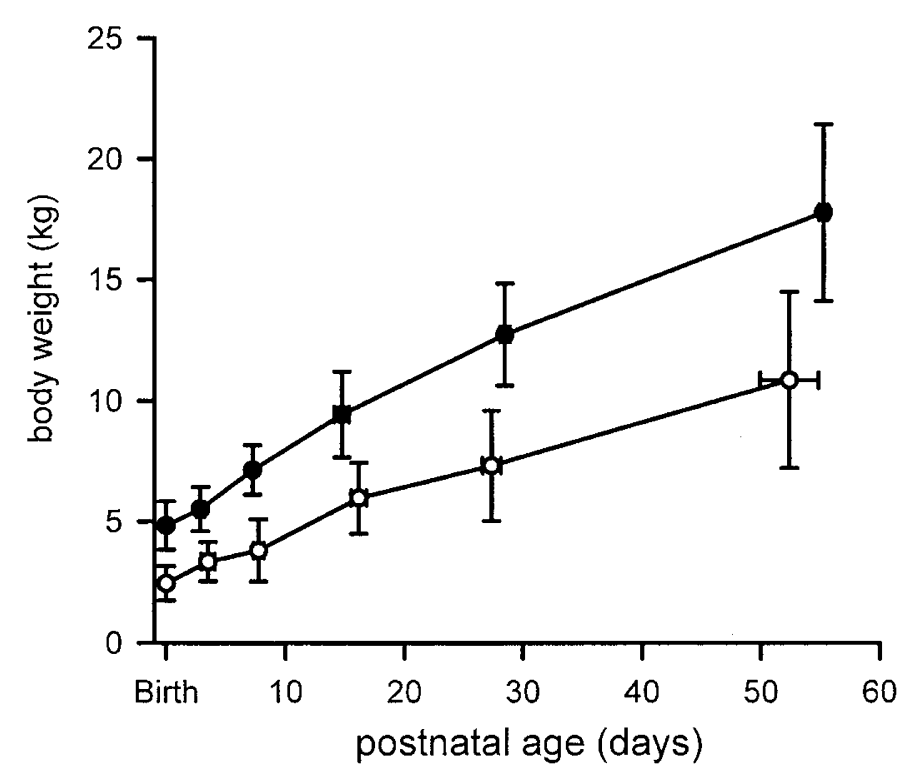

Figure 2. Body weights of IUGR $(\bigcirc)$ and control $(\bullet)$ lambs during the first 8 postnatal weeks. IUGR lambs weighed less than control lambs throughout the 8 -wk study period $(p<0.05)$. Where SD bars cannot be seen, they fall within the symbols.

The daily increments in body weight of IUGR lambs were less than those of controls $(169 \pm 49$ versus $274 \pm 34 \mathrm{~g} / \mathrm{d}, p<$ 0.01 ); however, in IUGR lambs, compared with controls, there was a significantly greater increase in body weight relative to birth weight during the 8 -wk period ( $438 \pm 63 \%$ versus $369 \pm$ $31 \%, p=0.01)$. However, at $8 \mathrm{wk}$, IUGR lambs remained lighter than controls (Table 2). At birth, the ponderal index was lower in IUGR lambs than in controls $(2.3 \pm 0.3$ versus $3.1 \pm$ $\left.0.4 \mathrm{~kg} / \mathrm{cm}^{3} \times 10^{-5}, p<0.05\right)$, supported by their wasted appearance, but at $8 \mathrm{wk}$ it was not significantly different between groups (Table 2).

Postnatal blood data. After birth, and in the absence of sedation, $\mathrm{PaO}_{2}$ was lower in IUGR lambs than in controls $(p<$ 0.05 ), particularly during the first $3 \mathrm{wk}$; however, $\mathrm{SaO}_{2}$ did not differ between groups (Fig. 3). $\mathrm{PaCO}_{2}$ tended to be higher in IUGR lambs than in controls $(41.4 \pm 1.9 \mathrm{~mm} \mathrm{Hg}$ versus $39.7 \pm 1.7 \mathrm{~mm} \mathrm{Hg}, p=0.08)$ whereas arterial $\mathrm{pH}(7.40 \pm$ $0.01)$ was not different between groups. There were no differences in blood glucose $(4.4 \pm 0.5 \mathrm{mmol} / \mathrm{L})$ and lactate $(0.9 \pm$ $0.2 \mathrm{mmol} / \mathrm{L}$ ) concentrations between IUGR and control lambs.
Table 2. Body dimensions and lung function data (mean $\pm S D$ ) in postnatal control $(\mathrm{n}=8)$ and IUGR $(\mathrm{n}=8)$ lambs as measured at 8 wk after birth

\begin{tabular}{|c|c|c|}
\hline & Control & IUGR \\
\hline Body weight $(\mathrm{kg})$ & $17.8 \pm 3.4$ & $10.9 \pm 3.4^{*}$ \\
\hline Crown rump length $(\mathrm{cm})$ & $88.0 \pm 4.9$ & $80.4 \pm 4.4 *$ \\
\hline Ponderal index $\left(\mathrm{g} / \mathrm{cm}^{3} \times 10^{5}\right)$ & $2.60 \pm 0.32$ & $2.29 \pm 0.39$ \\
\hline $\mathrm{TLC}_{30}(\mathrm{~mL})$ & $841.1 \pm 134.3$ & $559.4 \pm 146.4^{*}$ \\
\hline $\mathrm{FRC}(\mathrm{mL})$ & $378.9 \pm 63.0$ & $308.9 \pm 64.6^{*}$ \\
\hline $\mathrm{C}_{\mathrm{RS}}\left(\mathrm{mL} / \mathrm{cm} \mathrm{H}_{2} \mathrm{O}\right)$ & $15.1 \pm 3.1$ & $9.0 \pm 2.6^{*}$ \\
\hline $\mathrm{C}_{\mathrm{W}}\left(\mathrm{mL} / \mathrm{cm} \mathrm{H}_{2} \mathrm{O}\right)$ & $29.5 \pm 8.0$ & $31.8 \pm 18.5$ \\
\hline $\mathrm{C}_{\mathrm{L}}\left(\mathrm{mL} / \mathrm{cm} \mathrm{H} \mathrm{H}_{2} \mathrm{O}\right)$ & $34.8 \pm 12.3$ & $15.2 \pm 8.9^{*}$ \\
\hline $\mathrm{DL}_{\mathrm{CO}}(\mathrm{mL} / \mathrm{min} / \mathrm{mm} \mathrm{Hg})$ & $4.53 \pm 01.35$ & $3.24 \pm 1.53$ \\
\hline Ventilation (L/min) & $3.36 \pm 0.43$ & $2.46 \pm 0.21 *$ \\
\hline Breathing frequency (breaths/min) & $34.6 \pm 6.45$ & $38.4 \pm 11.4$ \\
\hline Tidal volume $(\mathrm{mL})$ & $98.5 \pm 31.7$ & $66.8 \pm 16.27^{*}$ \\
\hline Oxygen consumption (mL/min) & $139.9 \pm 41.3$ & $115.9 \pm 41.3$ \\
\hline
\end{tabular}

Asterisks $(*)$ indicate differences between groups $(p<0.05)$, when analyzed by the unpaired $t$ test.

Ventilation and oxygen consumption. Over the 8-wk study period (i.e. $3 \mathrm{~d}$ to $8 \mathrm{wk}$ ), minute ventilation adjusted for body weight was greater in IUGR lambs than in controls $(375 \pm 65$ versus $274 \pm 52 \mathrm{~mL} / \mathrm{min} / \mathrm{kg}, p<0.01$, Fig. 4). Over the same period, mean breathing frequency was greater in IUGR lambs than in controls $(52.4 \pm 8.4$ versus $43.6 \pm 7.2$ breaths $/ \mathrm{min}$, $p<0.05)$, whereas their tidal volume was not different to values in controls $(7.2 \pm 1.2$ versus $6.3 \pm 1.0 \mathrm{~mL} / \mathrm{kg})$.

Throughout the 8 postnatal weeks, $\mathrm{O}_{2}$ consumption $(\mathrm{mL} /$ min) was lower in IUGR lambs than in controls $(77.6 \pm 17.2$ versus $110.7 \pm 31.8 \mathrm{~mL} / \mathrm{min})$. However, when expressed in relation to body weight, $\mathrm{O}_{2}$ consumption was greater in IUGR lambs than in controls $(12.8 \pm 4.0$ versus $10.8 \pm 2.2$ $\mathrm{mL} / \mathrm{min} / \mathrm{kg}$ ).

Pulmonary gas volumes. Data on $\mathrm{FRC}$ and $\mathrm{TLC}_{30}$ for individual animals at 1 and $8 \mathrm{wk}$, related to body weight, are shown in Figure 5. Linear regression analysis of lung volume data showed that $\mathrm{FRC}$ and $\mathrm{TLC}_{30}$ were significantly correlated with body weight. Multiple linear regression analysis showed that, at $1 \mathrm{wk}, \mathrm{FRC}\left(p=0.001, r^{2}=0.83\right)$ and $\operatorname{TLC}_{30}(p=$ $\left.0.001, r^{2}=0.89\right)$ were significantly related to body weight; at 8 wk $\operatorname{TLC}_{30}\left(p=0.001, r^{2}=0.74\right)$ was significantly related to body weight.

FRC (unadjusted values, $\mathrm{mL}$ ) was significantly lower in IUGR lambs than in controls over the 8-wk study period (Fig. $6 A$ ). When adjusted for body weight (Fig. 6B), FRC was 


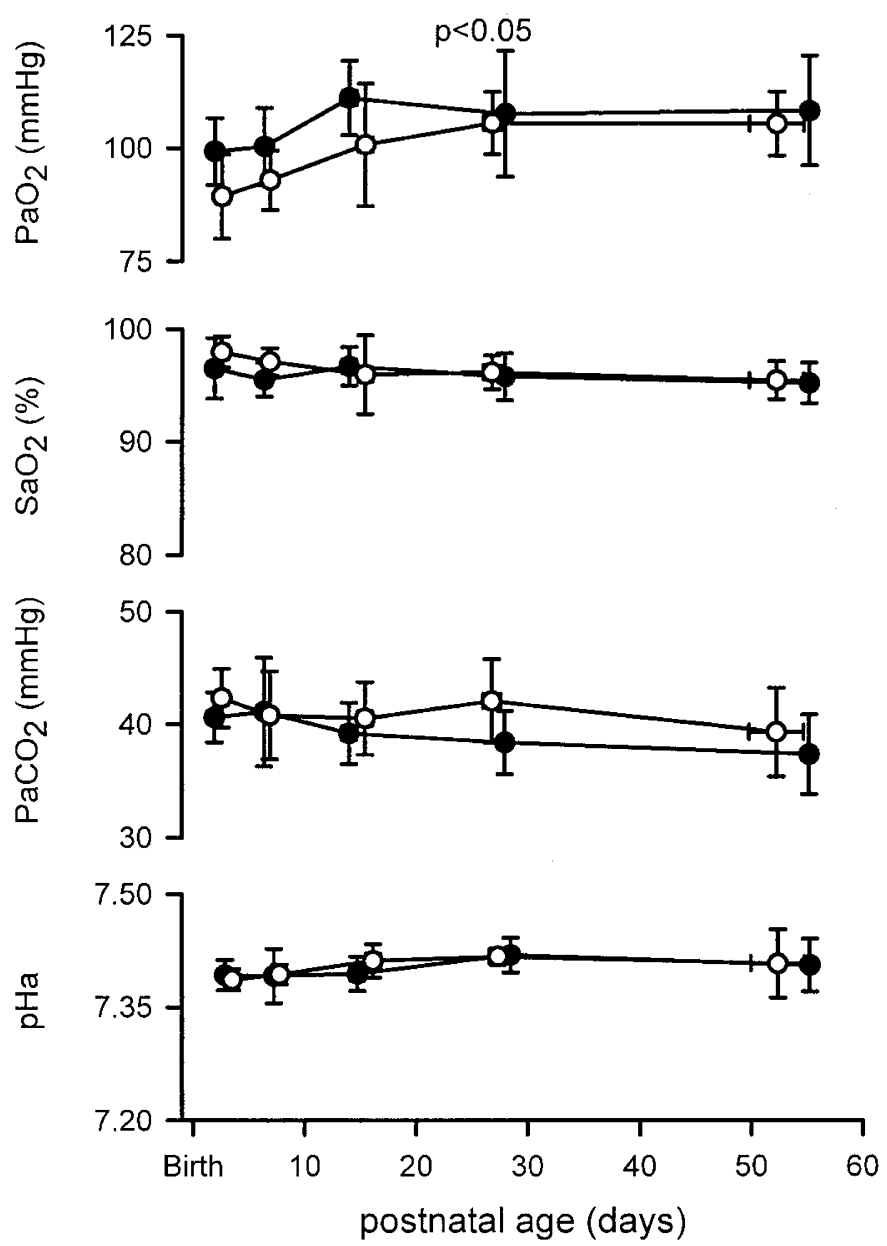

Figure 3. Arterial blood gas tensions and $\mathrm{pH}(\mathrm{pHa})$ in postnatal IUGR $(\bigcirc)$ and control $(-)$ lambs when unsedated. $\mathrm{PaO}_{2}$ was lower in IUGR lambs than in controls $(p<0.05)$ and $\mathrm{PaCO}_{2}$ tended to be higher $(p=0.08)$. $\mathrm{SaO}_{2}$, and $\mathrm{pHa}$ were not different between groups. Where SD bars cannot be seen, they fall within the symbols.

greater in IUGR lambs than in controls $(27.7 \pm 3.5$ versus 23.7 $\pm 3.8 \mathrm{~mL} / \mathrm{kg}$ ). TLC measured at $30 \mathrm{~cm} \mathrm{H}_{2} \mathrm{O}$ (unadjusted values) was significantly lower in IUGR lambs than in controls. When adjusted for body weight, values for $\mathrm{TLC}_{30}$ were greater in IUGR lambs than in controls $(57.2 \pm 4.3$ versus 50.4 $\pm 5.5 \mathrm{~mL} / \mathrm{kg}, p<0.05)$.

Pulmonary diffusing capacity. DLco (unadjusted) was lower in IUGR lambs than in controls throughout the 8 -wk study period $(1.55 \pm 0.73$ versus $2.95 \pm 0.76 \mathrm{~mL} / \mathrm{min} / \mathrm{mm} \mathrm{Hg}$, Fig. $7 A$ ). When expressed in relation to lung volume (FRC), DLco remained lower in IUGR lambs over this period $(0.008$ \pm 0.003 versus $0.012 \pm 0.002 \mathrm{~mL} / \mathrm{min} / \mathrm{mm} \mathrm{Hg} / \mathrm{mL}$, Fig. $7 B$ ).

Respiratory compliances. $\mathrm{C}_{\mathrm{RS}}$, expressed as unadjusted values $\left(\mathrm{mL} / \mathrm{cm} \mathrm{H}_{2} \mathrm{O}\right)$, was significantly lower in IUGR lambs than controls. When $\mathrm{C}_{\mathrm{RS}}$ was adjusted for FRC, it was significantly lower in IUGR lambs than in controls at 4 and 8 wk (Fig. 8A). Unadjusted values of $\mathrm{C}_{\mathrm{W}}$ were not different between groups; however, when adjusted for FRC, $\mathrm{C}_{\mathrm{W}}$ was greater $(p<0.05)$ in IUGR lambs (Fig. $8 B$ ). $\mathrm{C}_{\mathrm{L}}$, expressed as unadjusted values $\left(\mathrm{mL} / \mathrm{cm} \mathrm{H}_{2} \mathrm{O}\right)$, was significantly lower in IUGR lambs; when $\mathrm{C}_{\mathrm{L}}$ was adjusted for FRC, it was also significantly lower $(p<$ 0.05 ) in IUGR lambs than in controls (Fig. 8C).
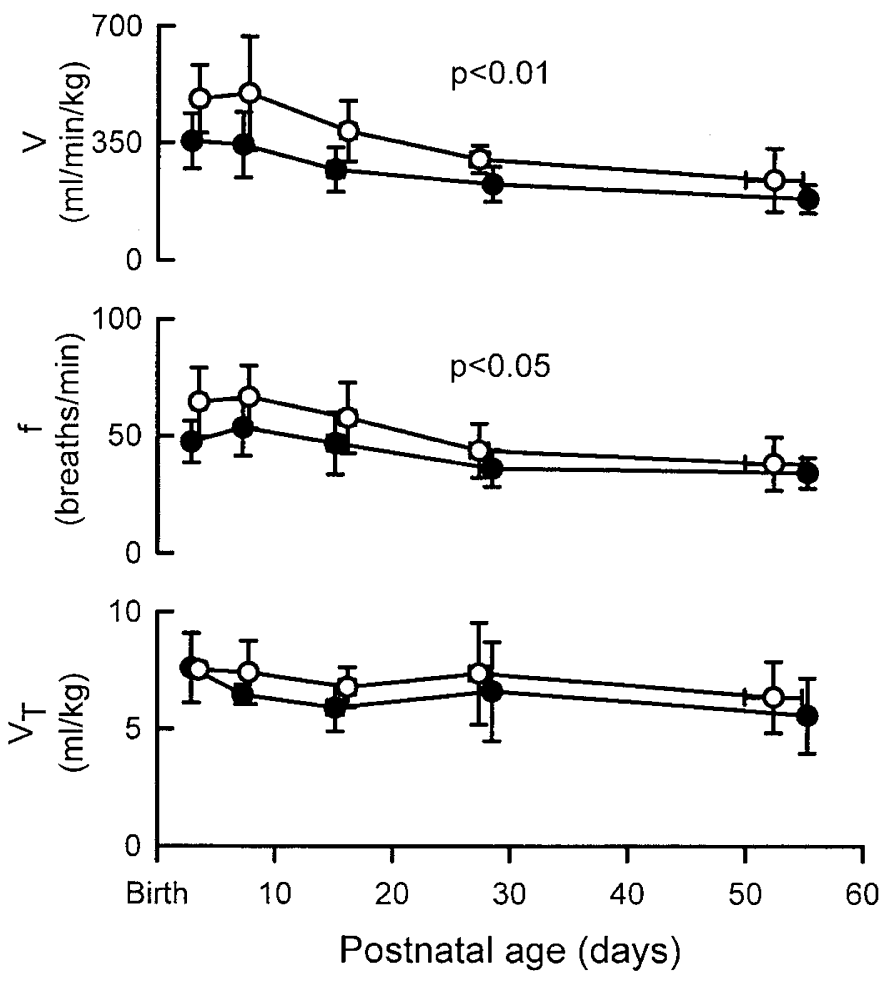

Figure 4. Minute ventilation $(V, \mathrm{~mL} / \mathrm{min} / \mathrm{kg}$ body weight $)$ and its components, breathing frequency $(f$, breaths $/ \mathrm{min})$ and tidal volume $\left(V_{T}, \mathrm{~mL} / \mathrm{kg}\right.$ body weight) in IUGR $(\bigcirc)$ and control $(\bullet)$ lambs during the first 8 postnatal weeks. Minute ventilation of IUGR lambs was greater than in controls, largely due to a greater breathing frequency. Where SD bars cannot be seen, they fall within the symbols.
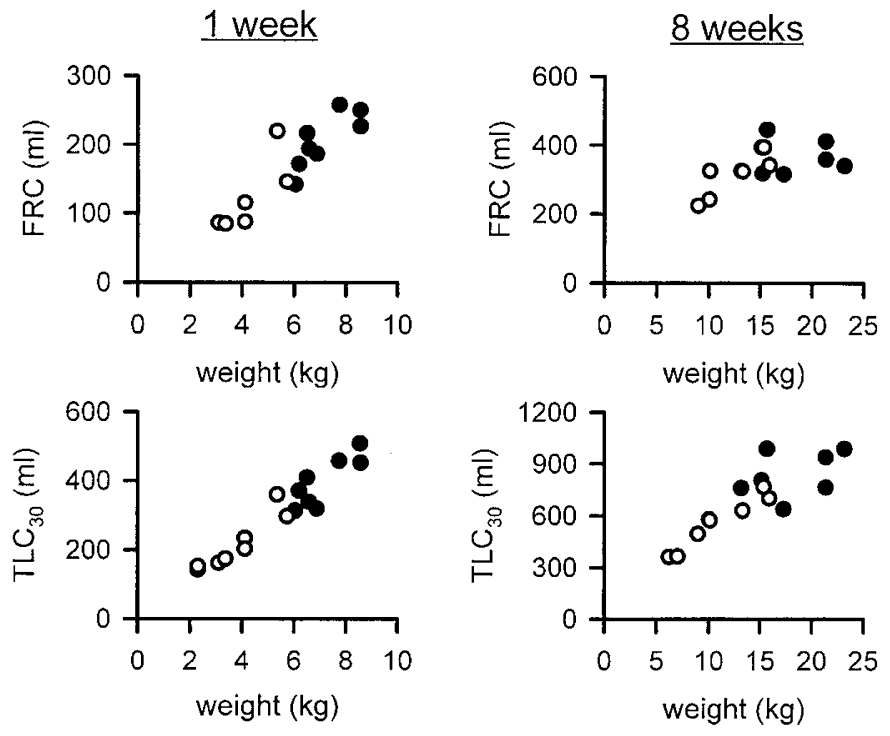

Figure 5. Values of $\mathrm{FRC}$ and $\mathrm{TLC}_{30}$ in relation to body weight in individual IUGR lambs $(\bigcirc)$ and control lambs $(\bullet)$ at 1 and 8 wk after birth. See text for details.

Lung function data at $8 \boldsymbol{w k}$. Data relating to lung function (unadjusted values), together with data on body weight and dimensions, in IUGR and controls lambs at $8 \mathrm{wk}$ after birth are presented in Table 2. At $8 \mathrm{wk}$, both FRC and $\mathrm{TLC}_{30}$ were smaller in IUGR lambs than in controls. Both $\mathrm{C}_{\mathrm{RS}}$ and $\mathrm{C}_{\mathrm{L}}$ were also lower in IUGR lambs than in controls at $8 \mathrm{wk}$, 



Figure 6. FRC in IUGR $(\bigcirc)$ and control lambs $(\bullet)$ during the first 8 wk after birth. Data are expressed as $(A)$ unadjusted values and $(B)$ values adjusted for body weight. Unadjusted FRC was lower in IUGR lambs than in controls $(p<$ 0.05 ); when adjusted for body weight, FRC was greater in IUGR lambs than in controls $(p<0.05)$. Where SD bars cannot be seen, they fall within the symbols.
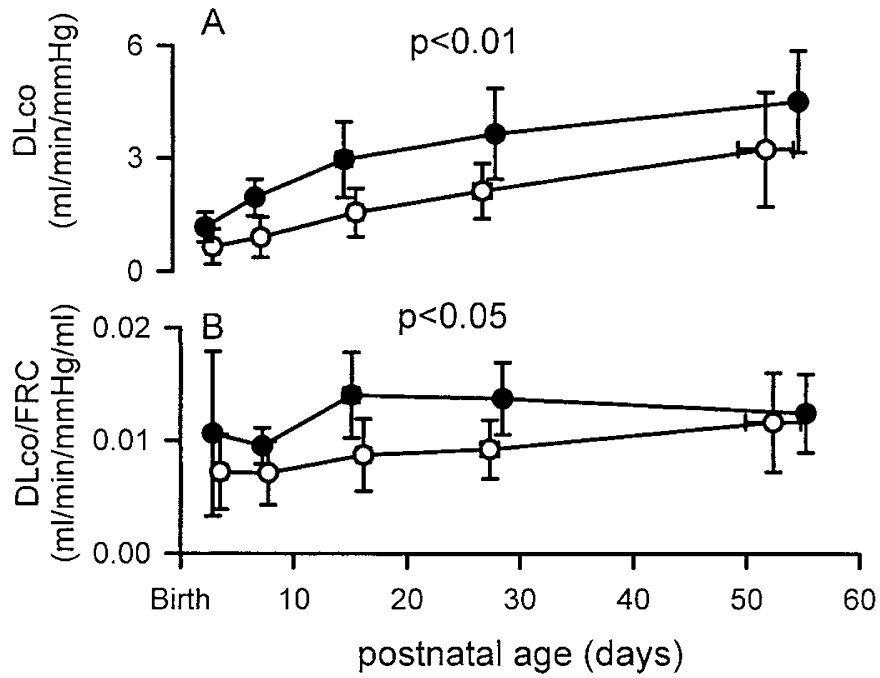

Figure 7. DLco in IUGR $(\bigcirc)$ and control $(\bullet)$ lambs. Unadjusted values $(A)$ increased with age in both groups of lambs but were lower in IUGR lambs than in controls $(p<0.01)$. When values were adjusted for FRC $(B)$, they were significantly lower in IUGR lambs than in controls $(p<0.05)$. Where SD bars cannot be seen, they fall within the symbols.

whereas $\mathrm{C}_{\mathrm{W}}$ was not different. Unadjusted values of minute ventilation and tidal volume were lower at $8 \mathrm{wk}$ in IUGR lambs compared with controls, but breathing frequency was not different (Table 2).

Lung weights and composition. Wet lung weights of IUGR lambs at $8 \mathrm{wk}$ tended to be lower than those of controls, but values were not different when adjusted for body weight (Table 3 ). Dry lung weights were $29 \%$ lower in IUGR lambs than in controls but were not different when adjusted for body weight. The percentage water content of the lungs was not different between IUGR and control lambs. Pulmonary DNA concentrations were $9 \%$ lower and pulmonary protein concentrations
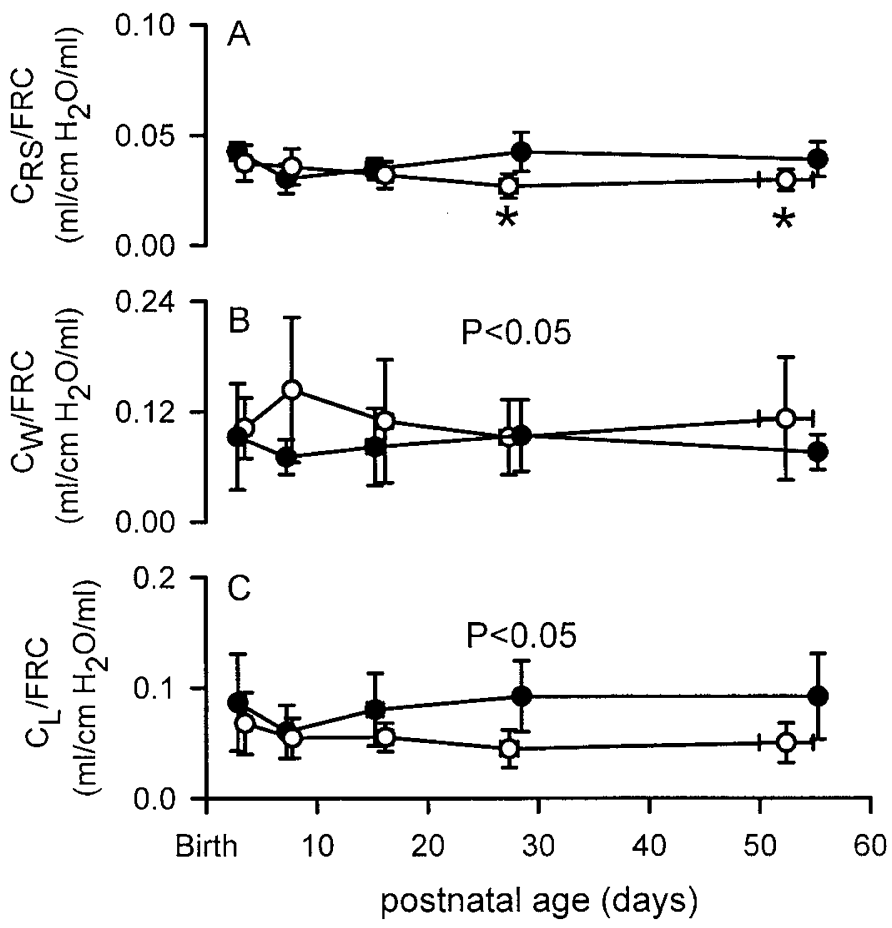

Figure 8. Static compliances of $(A)$ respiratory system $\left(\mathrm{C}_{\mathrm{RS}}\right),(B)$ chest wall $\left(\mathrm{C}_{\mathrm{W}}\right)$, and $(C)$ lungs $\left(\mathrm{C}_{\mathrm{L}}\right)$ in IUGR $(\bigcirc)$ and control $(\bullet)$ lambs, when adjusted for FRC. $\mathrm{C}_{\mathrm{RS}} \mathrm{S} / \mathrm{FRC}$ was significantly lower in IUGR lambs than in controls at 4 and $8 \mathrm{wk}\left({ }^{*} p<0.05\right) . \mathrm{C}_{\mathrm{W}} / \mathrm{FRC}$ was greater in IUGR lambs than in controls throughout the 8 week period $(p<0.05)$ whereas $\mathrm{C}_{\mathrm{L}} / \mathrm{FRC}$ was significantly lower in IUGR lambs compared with controls $(p<0.05)$. Where SD bars cannot be seen, they fall within the symbol.

Table 3. Measurements (mean $\pm S D$ ) made from the lungs of control $(\mathrm{n}=7)$ and IUGR $(\mathrm{n}=8)$ lambs at 8 wk after birth

\begin{tabular}{lcc}
\hline & Control & IUGR \\
\hline Wet lung weight $(\mathrm{g})$ & $231.3 \pm 49.2$ & $181.3 \pm 56.3 \dagger$ \\
Wet lung weight $(\mathrm{g} / \mathrm{kg} \mathrm{BWt})$ & $13.1 \pm 1.5$ & $17.2 \pm 7.7$ \\
Dry lung weight $(\mathrm{g})$ & $45.5 \pm 6.9$ & $32.2 \pm 13.1^{*}$ \\
Dry lung weight $(\mathrm{g} / \mathrm{kg} \mathrm{BWt})$ & $2.6 \pm 0.3$ & $2.9 \pm 0.8$ \\
Water content of lungs $(\%)$ & $80.1 \pm 2.1$ & $82.3 \pm 3.2$ \\
Lung DNA concentration $(\mathrm{mg} / \mathrm{g}$ lung) & $6.4 \pm 0.38$ & $5.8 \pm 0.33^{*}$ \\
Total lung DNA content $(\mathrm{g})$ & $1.4 \pm 0.3$ & $1.0 \pm 0.3^{*}$ \\
Total lung DNA content $(\mathrm{mg} / \mathrm{kg} \mathrm{BWt})$ & $85.5 \pm 9.3$ & $81.8 \pm 16.1$ \\
Lung protein concentration $(\mathrm{mg} / \mathrm{g}$ lung) & $135.3 \pm 14.6$ & $119.3 \pm 9.3^{*}$ \\
Total lung protein content $(\mathrm{g})$ & $29.9 \pm 4.9$ & $21.2 \pm 7.8^{*}$ \\
Total lung protein content $(\mathrm{g} / \mathrm{kg} \mathrm{BWt})$ & $1.8 \pm 0.07$ & $1.7 \pm 0.4$ \\
DNA/protein ratio & $0.05 \pm 0.005$ & $0.05 \pm 0.007$ \\
\hline
\end{tabular}

Asterisks $(*)$ indicate differences between groups $(p<0.05) . \dagger p=0.09$. BWt, body weight.

were $12 \%$ lower in IUGR lambs than in controls (both $p<$ $0.05)$. The ratio of DNA and protein concentrations was not different between groups.

Lung surfactant proteins. Pulmonary tissue concentrations of SP-A tended to be higher in IUGR lambs compared with controls $(7.9 \pm 1.0$ versus $6.0 \pm 1.9$ arbitrary units, $p=0.07)$. There were no differences in SP-A or SP-C mRNA levels between IUGR and control lambs. However, SP-B mRNA levels were higher in IUGR lambs compared with controls (8.5 \pm 2.4 versus $5.9 \pm 0.7$ arbitrary units). 


\section{DISCUSSION}

This study has shown that restriction of placental function during the last $25 \mathrm{~d}(0.18)$ of ovine gestation inhibits fetal growth but allows the birth of mature lambs near term. It is apparent that the IUGR induced by chronic placental insufficiency alters the development of the lung and chest wall without restricting growth of lung tissue in relation to body weight. By making serial measurements in the same postnatal animals, we have shown that IUGR adversely affects respiratory function for up to $8 \mathrm{wk}$ after birth. It is likely that some of the changes we observed may persist beyond the 8 -wk duration of this study owing to the limited ability of the lung to recover from early developmental deficits $(28-31)$. Our findings in sheep are consistent with evidence of impaired respiratory function in infants and children following IUGR (2-5) and maternal smoking during pregnancy $(32,33)$, a major cause of IUGR.

Blood gases and gas exchange. Apart from being mildly hypoxemic and having a tendency toward $\mathrm{CO}_{2}$ retention, postnatal IUGR lambs had a similar acid-base status to control lambs. During the first postnatal week there were opposing differences between $\mathrm{PaO}_{2}$ and $\mathrm{SaO}_{2}$ values, with $\mathrm{PaO}_{2}$ being lower and $\mathrm{SaO}_{2}$ tending to be the same or higher than in controls; this indicates that during the early postnatal period the relationship between $\mathrm{PaO}_{2}$ and $\mathrm{SaO}_{2}$ may have been altered due to a left shift in the $\mathrm{Hb}-\mathrm{O}_{2}$ dissociation curve that could have been caused by a persistence of fetal Hb in IUGR lambs. It is likely that the lower DLco (FRC adjusted) measured during the first 4 postnatal weeks was the reason for the relative hypoxemia observed during this period.

Ventilation and $\mathrm{O}_{2}$ consumption. Minute ventilation, when adjusted for body weight, was greater in IUGR lambs than in controls throughout the 8-wk postnatal period, largely due to a greater breathing frequency. We also found that IUGR lambs had higher levels of $\mathrm{O}_{2}$ consumption $(\mathrm{mL} / \mathrm{kg})$. An elevation in ventilation may be expected in animals with increased rates of $\mathrm{O}_{2}$ consumption owing to the increased requirement for alveolar gas exchange. It is well established that small animals have a greater metabolic rate in relation to body mass than larger animals (34). The increased weight-adjusted ventilation and rate of $\mathrm{O}_{2}$ consumption could be a result of altered body composition of IUGR lambs (i.e. if the proportion of metabolically active to nonmetabolically active components of body mass was greater than in control lambs). It is also possible that the ratio of body surface area to volume is altered in IUGR lambs (which may also have had reduced wool growth), favoring heat loss and hence an increase in weight-adjusted metabolic rate and ventilation. Furthermore, a reduction in ventilatory efficiency owing to the observed reduction in lung compliance and increase in chest wall compliance could have increased the work of breathing and hence $\mathrm{O}_{2}$ consumption.

Lung growth. There was no evidence from our measurements of lung volumes that, at birth, the lungs of IUGR lambs differed from those of control lambs, when values were related to body weight. This concurs with our earlier observation that there was no evidence of altered fetal lung liquid volume or lung hypoplasia (i.e. reduced cell number or weight of lungs per kg of body weight) in near-term fetal sheep following $20 \mathrm{~d}$ of placental embolization (35).

At $8 \mathrm{wk}$, there was still no evidence that the lungs of IUGR lambs were hypoplastic, as lung weights (wet and dry) and pulmonary DNA and protein contents were appropriate for body weight. However, analysis of lung tissue at 8 wk showed that cellularity was apparently altered in IUGR lambs as pulmonary DNA and protein concentrations were lower than in control lungs. These differences could have been caused by an increase in pulmonary water content in IUGR lambs, but this was found not to be the case. It is possible that the amount of insoluble structural proteins (i.e. extracellular matrix proteins), which would not have been measured in our protein assay, was increased in the lungs of IUGR lambs; such an increase, in the presence of normal lung tissue weights, could explain the reduced DNA and protein concentrations. This possibility is supported by the tendency for dry lung weight (adjusted for body weight) to increase in IUGR lambs whereas body weight adjusted DNA and protein contents of the lungs were reduced. Furthermore, morphometric analysis of the lungs at $8 \mathrm{wk}$ (23) indicates that alveolar septa and blood-air barriers were thicker in the lungs of IUGR lambs than in controls.

Pulmonary gas volumes (FRC and $\mathrm{TLC}_{30}$ ) were smaller in IUGR lambs compared with controls, presumably due to their smaller body dimensions. When adjusted for body weight, however, both gas volumes were greater in IUGR lambs, which is surprising as the lungs of IUGR lambs were less compliant than those of controls. The apparent increases may have been due to the tendency for the lungs of IUGR lambs to weigh more, in relation to body weight. In addition, FRC/BWt may have been increased as a result of an elevated breathing frequency.

Respiratory compliances. The static compliance of the respiratory system $\left(\mathrm{C}_{\mathrm{RS}}\right)$ was lower in IUGR lambs than in controls, but this was apparently due to their smaller size; when adjusted for functional lung size (FRC), the differences were reduced. Although $C_{R S}$ was unchanged by IUGR, there were opposing differences in the relative contributions from the lung and chest wall. That is, $\mathrm{C}_{\mathrm{L}}$ adjusted for FRC was reduced in IUGR lambs, indicating increased lung stiffness; a similar trend was apparent when $\mathrm{C}_{\mathrm{L}}$ was adjusted for body weight. Conversely, $\mathrm{C}_{\mathrm{W}}$ adjusted for $\mathrm{FRC}$ (or body weight) was greater in IUGR lambs, indicating that chest wall rigidity was lower than in controls. Thus, throughout their first 8 postnatal weeks, our IUGR lambs showed evidence of having relatively stiff lungs in a relatively compliant chest wall. This combination, suggestive of ventilatory inefficiency, may have increased the work of breathing of IUGR lambs, contributing to their increased rate of $\mathrm{O}_{2}$ consumption.

It is not clear at present why the lungs of IUGR lambs were relatively stiff, although it has been shown that lung development can be affected by nutritional restriction $(36,37)$. Surfactant deficiency was apparently not involved. Our measurements of normal or elevated surfactant protein levels both before birth (35) and at $8 \mathrm{wk}$ after birth (this study) do not support the existence of surfactant deficiency in IUGR lambs during the postnatal study period. Altered pulmonary DNA concentrations in the fetus at $140 \mathrm{~d}$ of gestation (35) and at 8 
wk after birth (this study), as well as our morphometric observations (23) suggest that the lung parenchyma may be structurally altered by IUGR. It is also possible that the deposition of structural proteins such as elastin and collagen may have been altered in IUGR lambs as undernutrition in developing rats has been shown to reduce pulmonary concentrations of connective tissue proteins including elastin (38).

At present, we have no explanation for the observed increase in SP-B expression and for the tendency for pulmonary SP-A content to increase. It is possible that these changes may have been a response to reduced lung compliance, but potential mechanisms are not apparent.

The increase in $\mathrm{C}_{\mathrm{W}}$ after IUGR could be a result of alterations in the structure of the rib cage, diaphragm, or abdominal wall resulting from prenatal nutrient restriction. For example, it is possible that altered bone mineralization, which is known to be a consequence of IUGR (39), could have made the ribs more compliant. Whatever the causes of the increase in $\mathrm{C}_{\mathrm{W}}$, the effects were still evident at $8 \mathrm{wk}$ and likely would have persisted beyond this age.

Mechanism of action of IUGR on lung development. It is now well established that intrauterine conditions to which the fetus is exposed during placental insufficiency, principally undernutrition, hypoxemia, and elevated blood levels of corticosteroids, can each affect lung development but in differing ways. Studies of developing animals have shown that both prenatal and early postnatal undernutrition can result in alterations in lung structure and function $(15,36,37)$; respiratory muscle development can also be affected by undernutrition (40). In the rat it has been shown that IUGR reduces glucose transport to the lungs (41) and this could impair their development. Thus, it is possible that the effects of IUGR on the lungs are attributable, at least in part, to fetal undernutrition.

Chronic exposure to hypoxia $(14,42)$ has also been shown to affect lung development. It is possible that, in the presence of the hypoxemia associated with IUGR, pulmonary $\mathrm{O}_{2}$ delivery is greatly reduced owing to a hypoxemia-induced reduction in pulmonary blood flow (43). It is of interest, however, that prolonged hypobaric hypoxia did not affect lung growth in the ovine fetus (44).

An altered endocrine environment, as seen in fetuses exposed to IUGR, could also play a role in altering lung development. An increase in circulating cortisol levels that has been observed in the growth restricted fetus $(10,45)$ could impact upon formation of alveoli, as elevated glucocorticoid levels in developing rats have this effect $(46,47)$. However, in our study, there was no evidence of elevated cortisol levels in IUGR lambs. In other studies, fetal growth restriction has been associated with a reduction in circulating levels of IGF and insulin, which could affect lung development (48).

Of necessity, many of our respiratory measurements were made while the animals were sedated and intubated, and it is possible that these conditions may have altered some of the values obtained, in particular absolute values of ventilation, $\mathrm{O}_{2}$ consumption, and possibly pulmonary gas volumes. However, both groups were treated similarly, and differences observed between groups and with age likely reflect physiologic differences that would be present in unsedated animals.
Human correlates. Our study may help explain why IUGR increases the risk for impaired respiratory function in infants, children and adults $(2-5,49)$. It may also help explain why maternal cigarette smoking, a common cause of IUGR, leads to altered lung function in offspring $(32,33)$. We used a severe model of late gestational IUGR to maximize the effects on lung development; the degree of growth restriction of our IUGR lambs may have been greater than in most cases of human IUGR. Twin lambs were included in the IUGR group to enhance the effects of embolization; in these animals, IUGR would have been partially due to reduced placental function associated with twin pregnancies. In this study, we have not assessed airway function, which can be a major cause of altered lung function. It is likely that IUGR impairs airway development, and we have recently found that the walls of larger airways, relative to their circumference, are thinner in IUGR ovine fetuses near term (50).

\section{CONCLUSIONS}

We have shown that IUGR induced during late gestation by chronic placental insufficiency results in persistent detrimental effects on respiratory function after birth. IUGR was followed by a postnatal reduction in pulmonary diffusing capacity, mild hypoxemia, and increases in metabolic rate and ventilation relative to body weight. Lung and chest wall mechanics were also affected. The persistent decrease in lung compliance could be due to alterations in lung structure induced by impaired fetal nutrition and/or hypoxemia. The observed reduction in chest wall stiffness in lambs following IUGR could also be attributable to impaired fetal nutrition (e.g. reduced calcium availability) and/or hypoxemia during fetal life, affecting the composition of the rib cage or the diaphragm. In combination, a reduced lung compliance and increased chest wall compliance would be expected to impair ventilatory efficiency. It remains to be established whether the observed alterations in lung and chest wall function persist further into postnatal life and whether they could explain altered respiratory function observed in human subjects whose growth was restricted in utero.

Acknowledgments. The authors thank Alex Satragno and Emily Camm for surgical and technical assistance. We also thank Andrea Lines and Jan Loose for assistance with surfactant protein and cortisol analyses, and Dr. David Johns for advice about lung function measurements.

\section{REFERENCES}

1. Kramer MS, Olivier M, McLean FH, Willis DM, Usher RH 1990 Impact of intrauterine growth retardation and body proportionality on fetal and neonatal outcome. Pediatrics 86:707-713

2. Tyson JE, Kennedy K, Broyles S, Rosenfeld CR 1995 The small for gestational age infant: accelerated or delayed pulmonary maturation? Increased or decreased survival? Pediatrics 95:534-538

3. Minior VK, Divon MY 1998 Fetal growth restriction at term: myth or reality? Obstet Gynecol 92:57-60

4. Rona RJ, Gulliford MC, Chinn S 1993 Effects of prematurity and intrauterine growth on respiratory health and lung function in childhood. Br Med J 306:817-820

5. Nikolajev K, Heinonen K, Hakulinen A, Lansimies E 1998 Effects of intrauterine growth retardation and prematurity on spirometric flow values and lung volumes at school age in twin pairs. Pediatr Pulmonol 25:367-370

6. Barker DJP, Godfrey KM, Fall C, Osmond C, Winter PD, Shaheen SO 1991 Relation of birth weight and childhood respiratory infection to adult lung function and death from chronic obstructive airways disease. BMJ 303:671-675 
7. Stein CE, Kumaran K, Fall CH, Shaheen SO, Osmond C, Barker DJ 1997 Relation of fetal growth to adult lung function in south India. Thorax 52:895-899

8. Owens JA, Owens PC, Robinson JS 1995 Experimental restriction of fetal growth. In: Hanson MA, Spencer JAD, Rodeck CH (eds) Fetus and Neonate: Growth. Cambridge University Press, Cambridge pp, 139-175

9. Kramer MS 1998 Socioeconomic determinants of intrauterine growth retardation. Eur J Clin Nutr 52:S29-S33

10. Robinson JS, Hart IC, Kingston EJ, Jones CT, Thorburn GD 1980 Studies on the growth of the fetal sheep. The effects of reduction of placental size on hormone concentrations in fetal plasma. J Dev Physiol 2:239-248

11. Soothill PW, Nicolaides KH, Campbell S 1987 Prenatal asphyxia, hyper-lactinaemia, hypoglycaemia and erythroblastosis in growth retarded fetuses. BMJ 294:1051-1053

12. Economides DL, Nicolaides KH, Campbell S 1991 Metabolic and endocrine findings in appropriate and small for gestational age fetuses. J Perinat Med 19:97-105

13. Merrill JD, Ballard RA 1998 Antenatal hormone therapy for fetal lung maturation. Clin Perinatol 25:983-997

14. Massaro D, Massaro GD 1997 Regulation of the architectural development of the lung. In: Crystal RG, West JB, Weibel ER, Barnes PJ (eds) The Lung: Scientific Foundations, 2nd Ed. Philadelphia, Lipincott-Raven, pp 1027-1034

15. Lechner AJ, Winston DC, Bauman JE 1986 Lung mechanics, cellularity, and surfactant after prenatal starvation in guinea pigs. J Appl Physiol 50:1610-1614

16. Trudinger BJ, Stevens D, Connelly A, Hales JR, Alexander G, Bradley A 1987 Umbilical artery flow velocity waveforms and placental resistance: the effects of embolization of the umbilical circulation. Am J Obstet Gynecol 157:1443-1448

17. Gagnon R, Challis J, Johnston L, Fraher L 1994 Fetal endocrine responses to chronic placental embolization in the late-gestation ovine fetus. Am J Obstet Gynecol 170:929-938

18. Cock ML, Harding R 1997 Renal and amniotic fluid responses to umbilicoplacental embolization for 20 days in fetal sheep. Am J Physiol 237:R1094-R1102

19. Alcorn D, Adamson TM, Maloney JE, Robinson PM 1981 A morphologic and morphometric analysis of fetal lung development in the sheep. Anat Rec 201:655667

20. Davey MG, Johns DP, Harding R 1998 Postnatal development of respiratory function in lambs studied serially between birth and 8 weeks. Respir Physiol 113:83-93

21. Johns DP, Jakubowska AE, McCrabb GJ, Harding R 1994 Measurement of lung diffusing capacity and functional residual capacity during the first postnatal month. Pediatr Pulmonol 17:347-53

22. Davey MG, Hooper SB, Tester ML, Johns DP, Harding R 1999 Respiratory function in lambs after in utero treatment of lung hypoplasia by tracheal obstruction. J Appl Physiol 87:2296-2304

23. Harding R, Tester ML, Moss TJ, Davey MG, Louey S, Joyce BJ, Hooper SB, Maritz GS 2000 Effects of intra-uterine growth restriction on the control of breathing and lung development after birth. Clin Exp Pharmacol Physiol 27:114-119

24. Lines A, Nardo L, Phillips ID, Possmayer F, Hooper SB 1999 Alterations in lung expansion affect surfactant protein A, B, and C mRNA levels in fetal sheep. Am J Physiol 276:L239-L245

25. Hooper SB, Han VKM, Harding R 1993 Changes in lung expansion alter pulmonary DNA synthesis and IGF-II gene expression in fetal sheep. Am J Physiol 265:L403L409

26. Bocking AD, McMillen IC, Harding R, Thorburn GD 1986 Effect of reduced uterine blood flow on fetal and maternal cortisol. J Dev Physiol 8:237-245

27. Snedecor GW, Cochran WG 1989 Statistical Methods, 8th Ed. Iowa State University Press, Ames, IA

28. Adamson IYR, King GM 1988 Postnatal development of rat lung following retarded fetal lung growth. Pediatr Pulmonol 4:230-236
29. Falconer AR, Brown RA, Helms P, Gordon I, Baron JA 1990 Pulmonary sequelae in survivors of congenital diaphragmatic hernia. Thorax 45:126-129

30. Hislop A, Reid L 1976 Persistent hypoplasia of the lung after repair of congenital diaphragmatic hernia. Thorax 31:450-455

31. Maritz GS, Dennis H 1998 Maternal nicotine exposure during gestation and lactation interferes with alveolar development in the neonatal lung. Reprod Fertil Dev 10:255261

32. Hoo AF, Henschen M, Dezateux C, Costeloe K, Stocks J 1998 Respiratory function among preterm infants whose mothers smoked during pregnancy. Am J. Respir Crit Care Med 158:700-705

33. Dezateux C, Stocks J 1997 Lung development and early origins of childhood respiratory illness. Brit Med Bull 53:40-57

34. Ford LE 1984 Some consequences of body size. Am J Physiol 247:H495-H507

35. Cock ML, Albuquerque C, Joyce BJ, Hooper SB, Harding R 2001 Effects of intrauterine growth restriction on lung liquid dynamics and lung development in fetal sheep. Am J Obstet Gynecol 184:209-216

36. Sahebjami H 1993 Nutrition and lung structure and function. Exp Lung Res 19:105124

37. Kalenga M, Gaultier C, Burri PH 1999 Nutritional aspects of lung development. In: Gaultier C, Bourbon JR, Post M (Eds) Lung Development. Oxford University Press, New York, pp 347-363

38. Sahebjami H, MacGee J 1985 Effects of starvation on lung mechanics and biochemistry in young and old rats. J Appl Physiol 58:778-784

39. Namgung R, Tsang RC 2000 Factors affecting newborn bone mineral content: in utero effects on newborn bone mineralisation. Proc Nutr Soc 59:55-63

40. Prakash YS, Fournier M, Sieck GC 1993 Effects of prenatal undernutrition on developing rat diaphragm. J Appl Physiol 75:1044-1052

41. Simmons RA, Gounis AS, Bangalore SA, Ogata ES 1992 Intrauterine growth retardation: fetal glucose transport is diminished in lung but spared in brain. Pediatr Res 31:59-63

42. Sekhon HS, Thurlbeck WM 1996 Time course of lung growth following exposure to hypobaria and/or hypoxia in rats. Respir Physiol 105:241-252

43. Heymann MA 1989 Regulation of the perinatal pulmonary circulation and the role of lipid mediators. In: Gluckman PD, Johnston BM, Nathanielsz PW (Eds) Advances in Fetal Physiology: Reviews in Honor of G.C. Liggins. Perinatology Press, Ithaca, NY, pp 55-68

44. Jacobs R, Robinson JS, Owens JA, Falconer J, Webster ME 1988 The effect of prolonged hypobaric hypoxia on growth of fetal sheep. J Dev Physiol 10:97-112

45. Gagnon R, Langridge J, Inchley K, Murotsuki J, Possmayer F 1999 Changes in surfactant-associated protein mRNA profile in growth-restricted fetal sheep. Am J Physiol 276:L459-L465

46. Tschanz SA, Damke BM, Burri PH 1995 Influence of postnatally administered glucocorticoids on rat lung growth. Biol Neonate 68:229-245

47. Massaro GD, Massaro D 1992 Formation of alveoli in rats: postnatal effect of prenatal dexamethasone. Am J Physiol 263:L37-L41

48. Robinson JS, Owens JA, Owens PC 1994 Fetal growth and fetal growth retardation. In: Thorburn GD, Harding R (Eds) Textbook of Fetal Physiology. Oxford University Press, Oxford, pp 83-94

49. Shaheen S 1997 The beginnings of chronic airflow obstruction. Brit Med Bull 53:58-70

50. Harding R, Wignarajah D, Joyce B, Louey S, Tester M 2000 Effects of fetal growth restriction on airway development in fetal and postnatal lambs. Am J Respir Crit Care Med 161:A566 